\title{
Boron Neutron Capture Therapy in Cancer: Past, Present and Future
}

\section{perspectiva}

\author{
MARIO A. PISAREV \\ MARIa Alejandra Dagrosa \\ GUILERMO J. JUVENAL
}

Division of Nuclear Biochemistry, Department of Radiobiology, National Atomic Energy

Commission and Department of Human Biochemistry, University of Buenos Aires School of Medicine, Buenos Aires,

Argentina.

Recebido em 07/12/06 Aceito em 17/12/06

\section{ABSTRACT}

Undifferentiated thyroid cancer (UTC) is a very aggressive tumor with no effective treatment, since it lacks iodine uptake and does not respond to radio or chemotherapy. The prognosis of these patients is bad, due to the rapid growth of the tumor and the early development of metastasis. Boron neutron capture therapy (BNCT) is based on the selective uptake of certain boron non-radioactive compounds by a tumor, and the subsequent irradiation of the area with an appropriate neutron beam. ${ }^{10} \mathrm{~B}$ is then activated to ${ }^{11} \mathrm{~B}$, which will immediately decay releasing alpha particles and ${ }^{7} \mathrm{Li}$, of high linear energy transfer (LET) and limited reach. Clinical trials are being performed in patients with glioblastoma multiforme and melanoma. We have explored its possible application to UTC. Our results demonstrated that a cell line of human UTC has a selective uptake of borophenylalanine (BPA) both in vitro and after transplantation to nude mice. Treatment of mice by BNCT led to a complete control of growth and cure of $100 \%$ of the animals. Moreover dogs with spontaneous UTC also have a selective uptake of BPA. At the present we are studying the biodistribution of BPA in patients with UTC before its application in humans. (Arq Bras Endocrinol Metab 2007;51/5:852-856)

Keywords: Thyroid; Cancer; Treatment; Boron; Neutrons

\section{RESUMO}

Terapia do Câncer por Captura de Nêutrons de Boro: Passado, Presente e Futuro.

O câncer indiferenciado de tiróide (CIT) é um tumor muito agressivo sem tratamento efetivo, uma vez que não capta iodo e não responde à radio ou quimioterapia. O prognóstico desses pacientes é ruim, devido ao rápido crescimento do tumor e surgimento precoce de metástases. A terapia por captura de nêutrons de boro (TCNB) é baseada na captação seletiva de certos compostos de boro não-radioativos pelo tumor, e à subsequente irradiação da área com um feixe de nêutrons apropriado. $\mathrm{O}{ }^{10} \mathrm{~B}$ é então ativado para ${ }^{11} \mathrm{~B}$, cujo decaimento imediato libera partículas alfa e ${ }^{7} \mathrm{Li}$, de alta transferência linear de energia (TLE) e alcance limitado. Ensaios clínicos estão sendo conduzidos em pacientes com glioblastoma multiforme e melanoma, e nós estamos explorando sua possível aplicação no CIT. Nossos resultados demonstram que uma linhagem celular do CIT humano mostra captação seletiva de borofenilalanina (BPA) tanto in vitro como após transplante em camundongos "nude". O tratamento de camundongos com TCNB leva a um controle completo do crescimento tumoral e à cura em $100 \%$ dos animais. Além disso, cães com CIT espontâneo também apresentam captação seletiva de BPA. No momento, estamos estudando a biodistribuição de BPA em pacientes com CIT, antes de sua aplicação em humanos. (Arq Bras Endocrinol Metab 2007;51/5:852-856)

Descritores: Tiróide; Câncer; Tratamento; Boro; Nêutrons 
A ROUND THE 1930s, a distinguished physicist, Dr. Lawrence, proposed a new form of therapy based on the possible uptake of non-radioactive boron compounds by a tumor. Once a selective uptake of boron was achieved, tumor/normal tissues ratios equal or greater than 3, the area could be irradiated with an appropriate neutron beam causing the ${ }^{10} \mathrm{~B}$ to be transformed into ${ }^{11} \mathrm{~B}$, which would disintegrate releasing an $\alpha$ particle and ${ }^{7} \mathrm{Li}$, which have high linear energy transfer (LET) and a very limited scope $(10 \mu \mathrm{m})$, thus killing the cancer cells with almost no damage to the surrounding normal tissues. This idea was first applied by Dr. Swift at the MIT in Boston to patients with glioblastoma multiforme. However, at that time, early fifties, the boron compounds available for this purpose were barely useful and therefore the results obtained were not very good. However, one of his fellows at that time, Dr. Hatanaka, continued his efforts once he was back in Japan, his homeland.

The trials performed now utilized another boron compound, borophenylalanine (BPA) and almost 200 patients were treated, mainly for brain tumors of high grade (including glioblastoma multiforme). In some patients this technique improved the patient's survival and new hopes were raised. Groups in the USA, Europe and Japan started new trials with more precise protocols, which included glioblastomas and skin melanomas. Another boron compound, sodium borocaptate (BSH) was also included in some studies. Dr. Mishima, in Japan, obtained encouraging results by using BPA in melanomas, and in Sweden very interesting results were obtained in glioblastomas $(1,2)$.

From the consensus established among the different groups around the world a number of conditions were established:

- tumors to be submitted to this therapy should be those who lack an efficient available therapy;

- Boron compounds should have no side effects;

- Boron compounds should remain in the tumor enough time to allow an appropriate time of irradiation;

- Boron concentration in the tumor should be at least 15 ppm and;

- 3 times greater that the normal tissues.

Experimental models were developed using rats or nude mice bearing cell lines of the proposed tumors, as well as in vitro cell cultures were also used to evaluate the possible usefulness of this therapy. The neutron beam should be tailored according to the depth of the tumor: thermal for superficial tumors, and epithermal for more deeply located tumors.

\section{THYROID CANCER}

From the histopathologic point of view, thyroid cancers are classified as differentiated (follicular and papillar) and undifferentiated (anaplasic). The first two have in general good prognosis and are treated by total thyroidectomy, completed by a therapeutic dose of 131I. The undifferentiated (UTC) lacks iodide uptake and has a worse prognosis since it also fails to adequately respond to radio or chemotherapy. UTC usually has a very short survival time due to its rapid capacity to cause metastasis. Therefore some years ago we started a series of studies in order to evaluate its possibility to be treated by BNCT.

\section{UPTAKE OF BPA IN IN VITRO STUDIES}

The UTC human cell line ARO (gently provided by Drs. G. Juillard, UCLA, USA and J. Fagin, Cincinnatti, USA) was incubated with increasing concentrations of BPA. As controls, normal cells of bovine thyroid and human follicular adenoma cells were also incubated. The boron uptake by the ARO cells was around 4-5 times larger than that concentrated by the other two types of cells. The uptake was then compared in proliferating and quiescent ARO cells, and no significant difference was observed. This indicates that since the uptake is the same regardless of the cell cycle state that BNCT could be effective with a single treatment, compared to conventional radiotherapy (3).

\section{UPTAKE OF BPA IN IN VIVO STUDIES}

ARO cells were transplanted subcutaneously into NIH nude mice. The growth of the tumor was continuous and very rapid. In some cases lung metastasis were observed, resembling the human UTC behavior (4). Fifteen days after transplantation mice were injected via i.p. with BPA at doses of 350 and $600 \mathrm{mg} / \mathrm{kg}$ body weight, and sacrificed at variable times. Samples of the tumor, normal endogenous thyroid, kidney, spleen, surrounding and distal skin, blood were obtained and their boron concentration was measured and related to each sample weight. The tumor/normal tissues ratios were calculated and the results again demonstrated a selective uptake by the tumor with a ratio larger than 3. The maximum peak was observed at $60 \mathrm{~min}$ with the $350 \mathrm{mg}$ BPA dose, while with the $600 \mathrm{mg} \mathrm{BPA}$ dose it was at $90 \mathrm{~min}$. Total boron was between 18-24 (22) ppm (3). 
The large uptake by the tumor could be reflecting a more active metabolism. Mishima et al. (5) showed with the use of ${ }^{18} \mathrm{~F}$ labeled BPA a net incorporation rate for tumor 4 times higher than normal tissues. The mechanism transport of BPA was analyzed in the gliosarcoma cell line GS- ${ }^{9} \mathrm{~L}$, and in the fibroblast cell line V79. The results supported the hypothesis that $\mathrm{BPA}$ is transported by the $\mathrm{L}$ amino acid transport system $(6)$.

\section{TREATMENT OF TRANSPLANTED NUDE MICE BY BNCT}

Nude mice after 15 days of being transplanted with the ARO cells were injected with the two doses of BPA and 60 or 90 min later were anesthetized and irradiated with a neutron beam at of the RA-6 reactor (Bariloche Atomic Center). The following animal groups were included: a) control, no treatment; b) irradiated without $\mathrm{BPA}$; c) $350 \mathrm{mg} / \mathrm{kg}$ bw + irradiation; d) $600 \mathrm{mg} / \mathrm{kg}$ bw + irradiation. All animals survived without damage. Some of them were sacrificed immediately after the irradiation ( $48 \mathrm{hs}$ ) and the DNA of the tumor was isolated and analyzed by the comet assay in order to evaluate (DNA) damage. The area of the comet was determined for each group. A positive correlation between the tail moment, as a measure of DNA damage, and the total absorbed physical doses were observed. The total physical dose increased from the group irradiated with the beam only to BNCT groups irradiated with increasing doses of BPA. It is known that the DNA damage induced by radiation and the capacity of repair by the cells depend on the quality of radiation. High LET radiation (alpha particle and heavy ions) is biologically more effective than those of low LET (gamma or X-rays) because it causes DNA lesions more complex and difficult to repair (Rydberg B, 1996).

The other animals were followed by measuring the tumor volume with a calliper up to 30 days and after sacrifice the histology of the tumor area was examined. Tumors continued growing in the control mice. In those irradiated without BPA there was a small growth halt during the first days but afterwards growth reassumed with a slope parallel to the controls. In the BPA + irradiation groups, a complete halt of tumor progression was observed in $100 \%$ of mice, being more pronounced in those which received $600 \mathrm{mg} / \mathrm{kg}$ bw. When the initial (14 days after transplant) tumor volume was considered, we observed that in those who had a $50 \mathrm{~mm}^{3}$ volume or less a complete histological disappearance of the tumor was observed in $50 \%$ of mice (7).

\section{UPTAKE OF A BORONATED PORPHYRIN (BOPP)}

After the encouraging results obtained with BPA, it was decided to try to optimize the BNCT application. Studies performed in animals bearing glioma cell line demonstrated that the injection of BOPP caused a significant boron uptake (8). BOPP,4-bis- $(\alpha, \beta$-didihidroxyethyl)-deutero-porphyrin IX is a boronated porphyrin that was synthesized by Kahl in 1989 and it has 40 atoms of boron-10 by molecule against one atom alone in the BPA molecule (9). Mice transplanted with the ARO cells were injected with variable doses of BOPP (kindly provided by Prof. SB Kahl, University of California at San Francisco, USA), administered via i.p. or i.v. However, in our model we failed to observe a selective boron uptake compared to normal tissues after 1 day of administration. Therefore another protocol was assayed. BOPP was injected via i.p. from 1-7 days before BPA and the boron uptake was measured $60 \mathrm{~min}$ after BPA administration. We observed that the combination of 5 days after BOPP and 60 min after BPA the boron uptake was $45 \mathrm{ppm}$, doubling the results obtained with BPA alone (10).

\section{TREATMENT WITH BNCT IN MICE INJECTED WITH BPA + BOPP}

Mice were transplanted with the ARO cells and after 15 days they were injected with BOPP, while BPA was administered 5 days before. One hour after BPA the animals were anesthetized and irradiated as mentioned above. The animals were followed during three months and complete stop in tumor progression and a complete disappearance of tumor cells was observed histologically in $100 \%$ of the mice (11).

\section{INFLUENCE OF A RADIOSENSITIZER, NICOTINAMIDE, ON BNCT TREATMENT}

In previous studies we have demonstrated that nicotinamide (NA) injection caused a significant increase to 131I treatment in normal and goitrous rats (12). This effect was related to the increase in thyroid blood flow. NA causes at the same time an increase in the expression of eNOS synthase and in the generation of peroxides, which are responsible for tissue damage (13). Therefore it was decided to investigate whether NA also increases the effect of a neutron beam. First the possible action of NA on boron uptake was studied demonstrating that it does not affect the uptake by the tumor. 
NA has been utilized in patients with head and neck tumors submitted to conventional external radiotherapy, with encouraging results $(14,15)$.

When NA was administered during 3 days prior to BPA + irradiation, a tendency to slightly improve the outcome of the treatment (submitted for publication), but further studies are required in order to evaluate its possible application in BNCT.

\section{STUDIES IN DOGS WITH SPONTANEOUS UTC}

Dogs present frequently UTC, which behaves similarly to the human tumor, causing dyspnea due to compression of the trachea and metastasis in the rest of the body. We studied the uptake of BPA in 8 dogs that had an indication of surgery at the School of Veterinary Sciences, University of Buenos Aires, with previous signed informed consent from the owners. The animals were anesthetized and infused during $60 \mathrm{~min}$ with a solution of BPA-fructose, and then transported to the operating room. Blood samples were obtained every $15 \mathrm{~min}$ and during surgery samples of normal thyroid and tumor were taken to measure boron concentration and for histopathology.

The boron concentration in the tumor was greater than that in blood or in normal thyroid, but with widespread values. When the histopathology was taken into consideration, the tumors were classified as homogeneous or heterogeneous, these last with areas of dead cells. A clear correlation was demonstrated between the quality of cellularity (amount of lived cells) and the boron uptake. We may then conclude that BNCT can be effective in killing active tumor cells (16).

\section{RADIOBIOLOGY OF TUMOR CELLS}

In order to apply BNCT to a tumor, it is necessary to considerate not only its size and shape but also the relative biological effectiveness factor (RBE) of the neutron beam and the compound biological effectiveness factor (CBE). These factors are used in dosimetric calculations for each kind of tumor in order to obtained the total physical absorbed dose in terms which permit the comparison with the conventional treatment (the particular boron compound intended to use). In collaboration with the group of the Massachusetts Institute of Technology (Cambridge, MA, USA) a series of studies was per- formed with ARO cells. The cells were incubated with BPA alone or with the mixture of BPA + BOPP and irradiated with increasing doses of either neutrons or with X-rays. The biological endpoint (generation of new cells) was evaluated by the colony formation assay and values of 3.9 and 2.6 for the $\mathrm{CBE}$ of $\mathrm{BPA}$ and $\mathrm{BPA}+\mathrm{BOPP}$, respectively, were obtained. The value obtained for the combination was consistent with being additive. For the neutron beam, the RBE gave a value of 1.2 (to be published).

\section{STUDIES IN PATIENTS WITH THYROID CANCER}

A protocol for biodistribution studies in humans was established and the approval of the procedure by the Research and Ethics Committees of seven hospitals in Buenos Aires was obtained, followed by the approval of the Ministry of Public Health of Argentina. In each case, the signed informed consent of the patients was also obtained. These studies are underway and so far 3 patients have been analyzed, but further studies are required in order to arrive to a conclusion.

Meanwhile, one patient with a relapsed papillary thyroid cancer was treated by BNCT in Japan in September 2003. No adverse effects were observed and the patient is alive up to date (17).

\section{STUDIES IN PATIENTS WITH OTHER TUMORS}

In Sweden, 17 patients with glioblastoma multiforme have been treated by BNCT, without significant side effects. However, the time elapsed is short to draw conclusions (18). In the USA, a total of 17 patients have been treated, two showed a complete radiographic response and 13 had measurable reduction in tumor volume (19). Melanomas have been benefited by the BNCT treatment $(20,21)$.

Kato et al. (22) analyzed the outcome of 21 patients with head and neck malignancies after application of BNCT. Most of them had a significant uptake of BPA and in 39\% the survival time was 39\%.

\section{ACKNOWLEDGEMENTS}

The authors wish to thank the grants support provided by the National Research Council (CONICET), the Secretary of Science and Technology (SEPCYT) and the University of Buenos Aires, Argentina. 


\section{REFERENCES}

1. Barth RF. A critical assessment of boron neutron capture therapy: an overview. J Neuro-Oncol 2003;62:1-5.

2. Barth RF, Soloway H, Pisarev MA. Terapia por captura de neutrones en boro (BNCT) en tumores de cerebro: estado actual y potencial futuro. Oncología 1998;21:1-18.

3. Dagrosa MA, Viaggi ME, Kreimann EL, Farias S, Garavaglia R, Agote $M$, et al. Selective uptake of p-borophenylalanine by undifferentiated thyroid carcinoma for boron neutron capture therapy. Thyroid 2002;12:7-12.

4. Viaggi ME, Dagrosa MA, Larripa I, Gangitano D, Cabrini RL, Juvenal GJ, et al. A new animal model for human undifferentiated thyroid carcinoma in nude mice. Thyroid 2003;13:529-36.

5. Mishima Y, Imahori $Y$, Honda C, Hiratsuka J, Ueda S, Ido T. In vivo diagnosis of human melanoma with positron emission tomography using specific melanoma-seeking 18F-DOPA analogue. J Neuro-oncol 1997;33:163-9.

6. Wittig A, Sauerwein WA, Coderre JA. Mechanisms of transport of p-borono-phenylalanine trough the cell membrane in vitro. Radiat Res 2000;153:173-80.

7. Dagrosa MA, Viaggi ME, Longhino J, Calzetta O, Edreira M, Cabrini RL, et al. Experimental application of boron neutron capture therapy (BNCT) to undifferentiated thyroid carcinoma (UTC). Int J Radiat Oncol Biol Phys 2003;57:1084-92.

8. Hill JS, Kahl SB, Kaye AH, Stylli SS, Koo MS, Gonzales MF, et al. Selective tumor uptake of a boronated porphyrin in an animal model of cerebral gliomas. Proc Natl Acad Sci USA 1992:89:1785-9.

9. Kahl SB, Koo MS. Synthesis and properties of tetrakiscarborane-carboxylate esters of 2, 4-bis (-dihydroxyethyl) deuteroporphyrin IX. In: Allen BJ, Moore DE, Harrington BV (eds). Progress in Neutron Capture Therapy for Cancer. New York: Plenum Press, 1992. pp. 223-6.

10. Dagrosa MA, Viaggi M, Rebagliati RJ, Batistoni D, Kahl SB, Juvenal GJ, et al. Biodistribution of boron compounds in an animal model of undifferentiated thyroid cancer for boron neutron capture therapy. Mol Pharm 2005;2:152-6.

11. Viaggi $M$, Dagrosa MA, Longhino J, Blaumann $\mathrm{H}$, Calzetta $\mathrm{O}$, Kahl SB, et al. Boron neutron capture therapy for undifferentiated thyroid carcinoma: preliminary results with the combined use of BPA and BOPP. Appl Radiat Isotopes 2004:61:905-11.

12. Agote $M$, Viaggi ME, Kreimann EL, Krawiec L, Dagrosa MA, Juvenal GJ, et al. Influence of nicotinamide on the radiosensitivity of normal and goitrous thyroid in the rat. Thyroid 2001;11:1005-9.

13. Robertson MA, Finochietto $P$, Gamba CA, Dagrosa MA, Viaggi $M$, Franco $M C$, et al. Nicotinamide increases thyroid radiosensitivity by stimulating nitric oxide synthase expression and the generation of organic peroxides. Horm Metab Res 2006;38:12-7.
14. Rojas A, Hodgkins RJ, Stratford MRL, Dennis MF, Johns H. Pharmacokinetics of variable doses of nicotinamide and tumor radiosensitisation with carbogen and nicotinamide: clinical considerations. Br J Cancer 1993;68:1115-21.

15. Horsman MR, Siemann DW, Chaplin DJ, Overgaard J. Nicotinamide as a radiosensitizer in tumours and normal tissues: the importance of drug and timing. Radiother Oncol 1997;45;167-74.

16. Dagrosa MA, Viaggi M, Rebagliati RJ, Castillo VA, Batistoni $D$, Cabrini $R L$, et al. Biodistribution of $p$-borophenylalanine (BPA) in dogs with spontaneous undifferentiated thyroid carcinoma (UTC). Appl Radiat Isot 2004;61:911-5.

17. Hiratsuka J, Morita N, Aihara T, Imajo Y, Maruhashi A, Ono K. First clinical trial of neutron capture therapy for thyroid cancer. In: Nakagawa Y, Kobayashi T, Fukuda H (eds). Proceedings of ICNCT-12. Kagawa, Japan, 2006. pp. 7-9.

18. Capala J, Stenstam BH, Sköld K, Rosenschold PM, Giusti V, Persson C, et al. Boron neutron capture therapy for globlastoma multiforme: clinical studies in Sweden. J Neuro-Oncol 2004;62:135-44.

19. Busse PM, Harling OK, Palmer MR, Kiger III WS, Kaplan J, Kaplan I, et al. A critical examination of the results of the Harvard-MIT NCT program phase I clinical trial of neutron capture therapy for intracranial disease. J Neuro-Oncol 2004;62:111-21.

20. Hiratsuka $\mathrm{H}$, Fukuda $\mathrm{H}$, Kobayashi $T$. Long-term outcome of BNCT for malignant melanoma. Proceedings $9^{\text {th }}$ International Symposium on Neutron Capture Therapy for Cancer. Osaka, Japan, 2000. pp. 165-6.

21. Roth BM, Bonomi MR, Gonzalez SJ, Rebagliati RJ, Menendez $P$, Santa Cruz GA, et al. BNCT clinical trials of skin melanoma patients in Argentina. In: Nakagawa Y, Kobayashi T, Fukuda $\mathrm{H}$ (eds). Proceedings of ICNCT-12. Kagawa, Japan, 2006. pp. 14-7.

22. Kato I, Ono K, Sakurai Y, Ohmae M, Kamida A, Fujita Y, et al. Boron neutron capture therapy for recurrent head and neck malignancies. In: Nakagawa Y, Kobayashi T, Fukuda H (eds). Proceedings of ICNCT-12. Kagawa, Japan, 2006. pp. 1-4.

Address for correspondence:

Mario A. Pisarev

Dept. Radiobiology, CNEA

Av. Del Libertador 8250

Buenos Aires 1429, Argentina

E-mail: pisarev@cnea.gov.ar 